\title{
A Simple Reverse Transcription-Polymerase Chain Reaction for Dengue Type 2 Virus Identification
}

\author{
Luiz Tadeu M Figueiredo/ ${ }^{+}$, Weber Chelli Batista, Akira Igarashi ${ }^{*}$
}

\begin{abstract}
Unidade Multidisciplinar de Pesquisa em Virologia, Faculdade de Medicina de Ribeirão Preto, Universidade de São Paulo, 14049-900 Ribeirão Preto, SP, Brasil *Department of Virology, Institute of Tropical Medicine,

Nagasaki University, 12-4 Sakamoto-machi, Nagasaki, Japan
\end{abstract}

We show here a simplified reverse transcription-polymerase chain reaction $(R T-P C R)$ for identification of dengue type 2 virus. Three dengue type 2 virus strains, isolated from Brazilian patients, and yellow fever vaccine 17DD, as a negative control, were used in this study. C6/36 cells were infected with the virus, and tissue culture fluids were collected after 7 days of infection period. The RT-PCR, a combination of $R T$ and PCR done after a single addition of reagents in a single reaction vessel was carried out following a digestion of virus with $1 \%$ Nonidet $P-40$. The $50 \mu$ l assay reaction mixture included 50 pmol of a dengue type 2 specific primer pair amplifying a 210 base pair sequence of the envelope protein gene, $0.1 \mathrm{mM}$ of the four deoxynucleoside triphosphates, $7.5 \mathrm{U}$ of reverse transcriptase, and $1 U$ of thermostable Taq DNA polymerase. The reagent mixture was incubated for 15 min at $37^{\circ} \mathrm{C}$ for RT followed by a variable amount of cycles of two-step PCR amplification $\left(92^{\circ} \mathrm{C}\right.$ for $60 \mathrm{sec}, 53^{\circ} \mathrm{C}$ for $60 \mathrm{sec}$ ) with slow temperature increment. The PCR products were subjected to $1.7 \%$ agarose gel electrophoresis and visualized with UV light after gel incubation in ethidium bromide solution. DNA bands were observed after 25 and 30 cycles of PCR. Virus amount as low as $10^{2.8} \mathrm{TCID}_{50} / \mathrm{ml}$ was detected by $R T$-PCR. Specific DNA amplification was observed with the three dengue type 2 strains. This assay has advantages compared to other RT-PCRs: it avoids laborious extraction of virus RNA; the combination of $R T$ and PCR reduces assay time, facilitates the performance and reduces risk of contamination; the two-step PCR cycle produces a clear DNA amplification, saves assay time and simplifies the technique.

Key words: dengue identification - dengue diagnosis - reverse transcription-polymerase chain reaction

The four dengue virus serotypes, designated 1 , 2,3 , and 4 , are positive sense, single-stranded RNA viruses belonging to the genus Flavivirus of the family Flaviviridae (WHO 1986). According to strict epidemiological criteria, dengue viruses are arboviruses (arthropod-borne viruses) transmitted by Aedes aegypti and Ae. albopictus mosquitoes (Wengler 1991). These viruses cause an important arboviral disease of man, dengue hemorrhagic fever and dengue shock syndrome (DHF/DSS) (Gubler 1987).

Since the mid-80s, dengue epidemics have occurred throughout Brazil, producing millions of infections. Dengue types 1 and 2 have been isolated during epidemics. The vast majority of the disease cases involved were not life-threatening. However, after the introduction of dengue type 2, hundreds of DHF/DSS cases have occurred in the states of Rio de Janeiro and Ceará causing several deaths (Figueiredo et al. 1995).

Research supported by Japan International Cooperation Agency, and Brazilian Agencies CNPq and CAPES.

${ }^{+}$Corresponding author. Fax: +55-16-633.6695

Received 28 November 1996

Accepted 3 February 1997
The identification of Brazilian dengue virus isolates has been done by using type-specific monoclonal antibodies in an immunofluorescence test utilizing infected mosquito cells fixed on microscope slides (Henchal et al. 1983). Reverse transcription (RT) followed by polymerase chain reaction (PCR) has been used for rapid and specific detection of flaviviruses including the dengue viruses (Shibata et al. 1990, Laille et al. 1991, Lanciotti et al. 1992, Morita et al. 1994, Beaty et al. 1995). We show here a simplified RT-PCR for detection and identification of dengue type 2 virus.

\section{MATERIALS AND METHODS}

Virus strains - The three dengue type 2 virus strains, CEA-2462, SPH125367 and TOC-213 (Table I), used in this study, were isolated from Brazilian patients, and kindly supplied by Dr Amélia Travassos da Rosa from Evandro Chagas Institute, Brazilian Health Ministry, Belém, State of Pará, and Dr Luiza Teresinha Madia de Souza from Adolpho Lutz Institute, State of São Paulo Health Ministry. Yellow fever vaccine virus 17DD (Fiocruz, Brazil) was used as a negative control. 
$\mathrm{C} 6 / 36$ (Ae. albopictus) cells were grown at $28^{\circ} \mathrm{C}$ in Leibovitz L-15 medium containing $6 \%$ heat-inactivated fetal bovine serum, $10 \%$ tryptose phosphate broth, $100 \mathrm{U} / \mathrm{ml}$ penicillin and $100 \mu \mathrm{g} / \mathrm{ml}$ streptomycin. The cells were infected with virus strains, and tissue culture fluids were collected as virus seeds after 7 days of infection with confirmation of the infection by indirect immunofluorescence (Henchal et al. 1983, Figueiredo 1990). Infected tissue culture fluids were stored at $-70^{\circ} \mathrm{C}$, and tenfold dilutions were prepared in tissue culture medium at time of the assay.

\section{TABLE I}

Dengue type 2 virus strains

\begin{tabular}{lll}
\hline Strain & Place of infection & Year \\
\hline DEN 2 CEA 2462 & Ceará & 1994 \\
DEN 2 SPH 125367 & Rio de Janeiro & 1991 \\
DEN 2 TOC 213 & Tocantins & 1991 \\
\hline
\end{tabular}

Titration of dengue type 2 CEA 2462 - C6/36 cells were added to 96-well cluster dishes (Corning, USA) in $100 \mu \mathrm{l}$ of tissue culture medium at a density of $2 \times 10^{4}$ cells per well. After $24 \mathrm{hr}$ the cells were infected with $50 \mu 1$ of tenfold dilutions of dengue type 2 CEA 2462 , starting from $10^{-0}$ to $10^{-5}$, with 6 wells for each virus dilution. After a 5 day incubation period, all the wells received $50 \mu \mathrm{l}$ of neutral buffered formalin $(\mathrm{pH} 7)$ and were held overnight at $4^{\circ} \mathrm{C}$.

An enzyme immunoassay was performed after washing the microplate wells twice in phosphate buffered saline (PBS; Gibco BRL, USA). $100 \mu \mathrm{l}$ of dengue type 2 mouse polyclonal antiserum diluted $1 / 100$ in PBS containing $0.5 \%$ bovine serum albumin (BSA) was added to the wells. After $1 \mathrm{hr}$ at $37^{\circ} \mathrm{C}$ and 3 washes with PBS, horseradish peroxidase-conjugated goat anti-mouse IgG (Sigma, USA) diluted $1 / 2000$ in $0.5 \%$ BSA-PBS was added to the wells. Microplates were maintained for $1 \mathrm{hr}$ at $37^{\circ} \mathrm{C}$ and washed 5 times in PBS. Results were read spectrophotometrically $(414 \mathrm{~nm}), 30 \mathrm{~min}$ after the addition of ABTS substrate (Kirkegaard and Perry, USA) to the microplate wells (Figueiredo \& Shope 1987).

Infected wells were determinated as positives when their OD exceeded 3 SD of the mean value for control wells in the assay. The virus titer $\left(\mathrm{TCID}_{50}\right)$ was calculated by the method of Reed and Muench (1938).

Primers - Dengue type 2 specific primers amplifying a 210 base pair sequence of the envelope protein gene, were synthesized by Gibco BRL (USA) (Deubel et al. 1988, Morita et al. 1993, Tanaka 1993). Primer sequences and position in the virus genome are shown in Table II.
TABLE II

Nucleotide sequences and genome position of dengue primers

\begin{tabular}{lcc}
\hline Code & Sequence & Position \\
\hline DEN2-S & GTT CCT CTG CAA ACA CTC CA & $1203-1222$ \\
DEN2-C & GTG TTA TTT TGA TTT CCT TG & $1432-1413$ \\
\hline
\end{tabular}

$S$ : sense primer; $C$ : complementary primer

$R T$-PCR - The test was done in $500 \mu 1$ Eppendorf tubes by adding $1 \mu \mathrm{l}$ of infected tissue culture fluid (different dilutions were used), and $5 \mu \mathrm{l}$ of a detergent mixture containing $1 \%$ Nonidet P-40 and $5 \mathrm{U}$ of RNase inhibitor (Pharmacia, USA) in PBS. After $60 \mathrm{sec}$ of incubation at room temperature for virus solubilization, the cDNA was added to a reaction mixture containing $50 \mathrm{pmol}$ of the primer pair, 0.1 $\mathrm{mM}$ of the four deoxynucleoside triphosphates, 7.5 $\mathrm{U}$ of reverse transcriptase (Pharmacia, USA), $1 \mathrm{U}$ of Taq DNA polymerase (Pharmacia, USA), and $5 \mu \mathrm{l}$ of a buffer solution containing $5 \mathrm{mM}$ Tris ( $\mathrm{pH} 9.0$ ), $0.75 \mathrm{mM} \mathrm{MgCl}_{2}$, and $25 \mathrm{mM} \mathrm{KCl}$. A total volume of $50 \mu \mathrm{l}$ was obtained by adding distilled and deionized water. The reaction mixture was covered with 2 drops of oil and was incubated for $15 \mathrm{~min}$ at $37^{\circ} \mathrm{C}$ for RT, followed by 15 to 30 cycles of a two step PCR amplification $\left(92^{\circ} \mathrm{C}\right.$ for $60 \mathrm{sec}, 53^{\circ} \mathrm{C}$ for $60 \mathrm{sec}$ ) in a thermal cycler (Techne, UK). The temperature increment was slow, taking $120 \mathrm{sec}$ from $53^{\circ} \mathrm{C}$ to $92^{\circ} \mathrm{C}$, and $15 \mathrm{sec}$ from $70^{\circ} \mathrm{C}$ to $75^{\circ} \mathrm{C}$. The total time for the test was $150 \mathrm{~min}$.

Eight $\mu$ l of each PCR product was subjected to electrophoresis in a $1.7 \%$ agarose gel. PCR product nucleotide was visualized in UV light after incubation of the gel in a $0.5 \mu \mathrm{g} / \mathrm{ml}$ ethidium bromide solution for $20 \mathrm{~min}$, and rinsing with tap water. The size of the amplified DNA fragments was determined by comparing their migrations in the gel with those of the bands of a 100 base pair molecular weight marker (Pharmacia, USA).

\section{RESULTS}

The undiluted dengue type 2 CEA 2462 seed was processed at 20, 25 and 30 cycles of PCR after RT, in order to determine the ideal number of amplifications for the test. DNA bands of 210 base pairs were observed after 25 and 30 cycles. From this result, 30 cycles was considered as suitable for the test.

For evaluation of sensitivity of the RT-PCR, the $10^{4,8} \mathrm{TCID}_{50} / \mathrm{ml}$ dengue type 2 CEA 2462 virus seed was tested at serial tenfold dilutions. Amplified 210 base pair DNA bands were observed at $10^{-2}$ (weak band), $10^{-1}$, and $10^{-0}$ dilutions (Fig. 1).

DNA amplification was not observed in some 


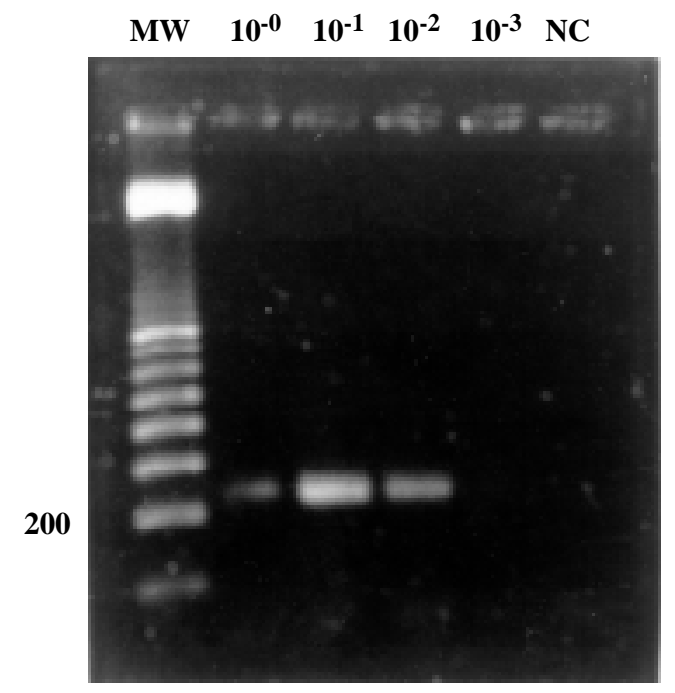

Fig. 1: photograph of an agarose gel stained with ethidium bromide, showing 210 DNA base pair bands obtained from a tenfold serial dilution for titration of dengue type 2 CEA-2462 amplified by reverse transcription-polymerase chain reaction (RT-PCR).

NC: negative control (RT-PCR product of yellow fever virus).

assays when undiluted virus seeds were processed, though a clear DNA amplification was obtained with the same virus seed at $10^{-1}$ dilution (Fig. 2).

Specific DNA amplification was observed with dengue type 2 CEA 2462, SPH 125367 and TOC 213 at $10^{-1}$ dilution. DNA amplification was not observed with yellow fever virus (Fig. 2).

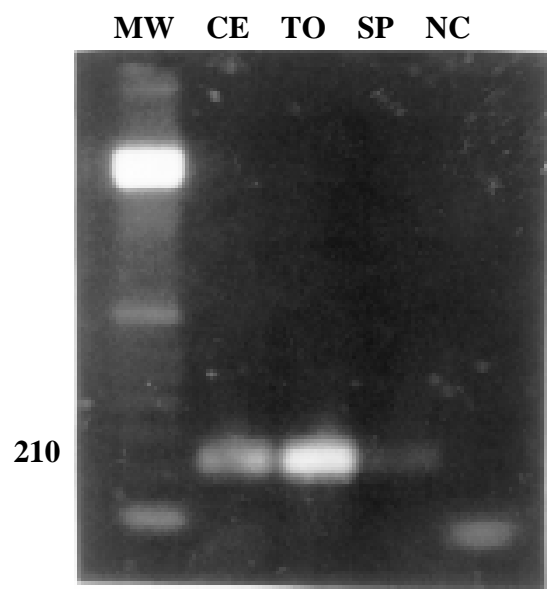

Fig. 2: photograph of an agarose gel stained with ethidium bromide, showing the specific DNA amplification by reverse transcription-polymerase chain reaction of the three dengue type 2 virus seeds at $10^{-1}$ dilution. Yellow fever virus was used as a negative control.

\section{DISCUSSION}

The dengue type 2 specific primers utilized in this assay have been previously studied (Tanaka 1993, Morita et al. 1993, 1994). The high specificity of the 210 base pair sequence of the envelope protein gene produced in this study was exhaustively confirmed in the papers cited (Tanaka 1993, Morita et al. 1993, 1994) eliminating the need for further confirmation by hybridization or nested PCR. Also, the absence of DNA amplification of yellow fever virus excludes the possibility of any nonspecific amplification related to the virus, the cell culture or the nutrient medium in our study. Three dengue type 2 virus seeds obtained from cells which had confirmed infection by immunofluorescence, were amplified by RT-PCR, showing a good correlation between these techniques.

Two-step PCR cycles have been reported as generating as much DNA as three-step cycles, at least for fragments about 200 base pairs long or less (Cha \& Thilly 1995). A suitable extension of DNA in two-step PCR is accomplished by the high processivity of taqDNA polymerase action which occurs during the temperature transition of $53^{\circ} \mathrm{C}$ to $92^{\circ} \mathrm{C}$. The optimal Taq DNA polymerase reaction range temperature from 70 to $75^{\circ} \mathrm{C}$, took 15 sec in the cycles of our RT-PCR (Cha \& Thilly 1995).

The 30 cycles of RT-PCR gave a very high sensitivity and a suitable amplification efficiency, since virus titers as low as $10^{2,8} \mathrm{TCID}_{50} / \mathrm{ml}$ could be detected. Virus titers in the blood during the first 6 days of dengue infection are commonly higher than this level, so the presence of the virus could be detected by RT-PCR (Gubler et al. 1981). However, in some tests, DNA amplification was not observed when undiluted virus seeds were processed, despite a clear DNA amplification obtained with the same virus seed at $10^{-1}$ dilution. Water used as sample diluent in our RT-PCR probably reduces RNAse, reverse transcriptase or DNA polymerase inhibitors from the C6/36 cells, or reduces RNA excess present in straight samples inhibiting reverse transcriptase.

Compared to other reported assays (Shibata et al. 1990, Laille et al. 1991, Lanciotti et al. 1992, Tanaka 1993, Morita et al. 1993, 1994, Beaty et al. 1995) our RT-PCR shows the following advantages: (i) solubilization of the virus by detergent mixture (Nonidet P-40 and RNAse inhibitor) prior to the RT-PCR, avoids laborious extraction of virus RNA especially when assaying many samples; (ii) the combination of RT and PCR which can be carried out after single addition of reagents in a single reaction vessel, reduces assay time, facilitates the performance and reduces the risk of con- 
tamination; (iii) the use of small amount of reagents (1U of Taq DNA polimerase, 7.5 U of reverse transcriptase, $50 \mathrm{pmol}$ of the primer pair) indicates that the method is reasonably economical. This makes the technique applicable even in the third world countries such as Brazil; (iiii) the two-step PCR cycles produce a clear DNA amplification, saves assay time and simplify the technique.

An obvious application of this RT-PCR is for confirming dengue type 2 virus isolation from patients or mosquitoes, in tissue culture fluids. We intend to extend the use of this technique to other dengue serotypes, and, since dengue outbreaks presently occur in Brazil, we will test the amplification of dengue virus genome from clinical specimens.

\section{ACKNOWLEDGEMENTS}

To Dr Benedito Fonseca for helpful suggestions, Mrs Rita Helena Carlucci for technical assistance, and Dr David DeJong for review of the manuscript.

\section{REFERENCES}

Beaty BJ, Calisher CH, Shope RE 1995. Arboviruses, p. 189-212. In EH Lennette, DA Lennete, ET Lennete (eds) Diagnostic procedures for viral, rickettsial, and chlamydial infections, 7th ed., American Public Health Association, Washington, D.C.

Cha RS, Thilly WG 1995. Specificity, efficiency, and fidelity of PCR, p. 37-52. In CW Dieffenbach, GS Dveksler (eds) PCR primer a laboratory manual. Cold Spring Harbor, New York.

Deubel VR, Kinney RM, Trent DW 1988. Nucleotide sequence and deduced amino acid sequence of the nonstructural proteins of Dengue type 2 virus, Jamaica genotype: comparative analysis of the full lenght genome. Virology 165: 234-244.

Figueiredo LTM, Shope RE 1987. An enzyme immunoassay for dengue antibody using infected cultured cells as antigen. J Virol Method 17: 191-198.

Figueiredo LTM, Owa MA, Carlucci RH, Mello NV, Fabbro AL, Capuano DM, Santili MB 1995. Dengue serologic survey in Ribeirão Preto, SP, Brazil.
Bull PAHO 29: 59-69.

Gubler DJ 1987. Current research on dengue, p. 623630. In Current Topics in Vector Research. SpringerVerlag, New York.

Gubler DJ, Suharyono W, Tan R, Abidin M, Sie A 1981. Viraemia in patients with naturally acquired dengue infection. Bull WHO 59: 623-630.

Henchal EA, Mc Cown JM, Seguin MK, Gentry MK, Brandt WE 1983. Rapid identification of dengue virus isolates by using monoclonal antibodies in an indirect immunofluorescence assay. Am J Trop Med Hyg 32: 164-169.

Laille M, Deubel V, Sainte-Marie FF 1991. Demonstration of concurrent dengue 1 and dengue 3 infection in six patients by the polimerase chain reaction. $J$ Med Virol 34: 51-54.

Lanciotti RS, Calisher CH, Gubler DJ, Chang G-J, Vorndan AV 1992. Rapid detection and typing of dengue viruses from clinical samples by using reverse transcriptase-polymerase chain reaction. J Clin Microbiol 30: 545-551.

Morita K, Tanaka M, Igarashi A 1993. Rapid identification of dengue virus serotypes by using polymerase chain reaction. J Clin Microbiol 29: 2107-2110.

Morita K, Maemoto T, Honda S, Onishi K, Murata M, Tanaka M, Igarashi A 1994. Rapid detection of virus genome from imported dengue fever and dengue hemorrhagic fever patients by direct polymerase chain reaction. $J$ Med Virol 44: 54-58.

Reed LJ, Muench H 1938. A simple method of estimating fifty per cent end-points. Am J Hyg 27: 493 497

Shibata M, Kudo T, Kajiyama M, Takahashi T, Matsushima M, Kimura H, Kuzushima K, Morishita T 1990. Hepatitis $C$ viral sequences in sera during the acute phase of infection. Am J Med 89: 830-832.

Tanaka M 1993. Rapid identification of flavivirus using the polymerase chain reaction. J Virol Method 41: 311-322.

Wengler G 1991. Family Flaviviridae. In RIB Francki, Classification and nomenclature of viruses - Fifth report of the International Committee on Taxonomy of Viruses. Arch Virol (Suppl. 2): 230-231.

WHO 1986. Dengue haemorrhagic fever: diagnosis, treatment and control, Geneva, $25 \mathrm{pp}$. 